\title{
KONSTRUKSI SOSIAL MASYARAKAT TERHADAP REALITAS SOSIAL TRADISI SI SEMBA' DI ERA GLOBALISASI (Studi penelitian di Daerah Kandeapi Tikala, Toraja Utara)
}

\author{
Oleh: Iga Sakinah Mawarni' ${ }^{\text {, Andi Agustang² }}$ \\ ${ }^{12}$ Program Studi pendidikan Sosiologi Fakultas Ilmu Sosial dan Hukum \\ Universitas Negeri Makassar \\ Email:igasakinah1o@gmail.com ${ }^{1}$,andi.agustang@unm.ac.id ${ }^{2}$
}

\begin{abstract}
Abstrak
Penelitian ini bertujuan untuk mengetahui 1) Gambaran konstruksi sosial masyarakat terhadap tradisi si semba', 2) Nilai pendidikan yang terkandung dalam tradisi si semba', 3) faktor pendukung eksistensi tradisi si semba' di era globalisasi. Jenis penelitian ini merupakan jenis penelitian kualitatif. Jumlah informan dalam penelitian ini sebanyak 12 orang yang ditentukan melalui teknik purposive sampling yaitu meminta masyarakat sebagai informan. Teknik pengumpulan data yang dilakukan yaitu wawancara, dan dokumentasi. Teknik pengabsahan data menggunakan membercheck. Hasil penelitian menunjukkan bahwa 1) konstruksi sosial masyarakat terhadap tradis si semba' adalah tradisi ini merupakan tradisi yang dilaksanakan setiap musim panen tiba dengan bentuk permainan saling adu kaki, Adapun tujuan dari tradisi ini adalah untuk menjalin silaturahmi, konstruksi sosial masyarakat terbentuk dengan 3 tahapan yaitu eksternalisasi yaitu tradisi ini merupakan tradisi yang sudah mandarah daging, tahapan obyektivasi yaitu sebuah kebiasaan yang dilakukan rutin, dan internalisasi adalah cara memaknai sebuah tradisi. 2) Nilai pendidikan yang terkandung dalam tradisi si semba' yaitu dapat membentuk jiwa solidaritas dengan saling bekerja sama satu sama lain, membangun jiwa sosial dengan menjalin silaturahmi, dan mengajarkan untuk tidak menyimpan dendam. 3) faktor pendukung eksistensi tradisi si semba' di era globlaisai adalah tetap mempertahankan tradisi dan melestarikannya dengan memanfaatkan perkembangan teknologi yaitu mangandalkan media sosial yang dijadikan sebagai wadah untuk melestarikan tradisi.
\end{abstract}

Kata Kunci: Konstruksi Sosial, Tradisi Si Semba', Globalisasi

\section{PENDAHULUAN}

Kontruksi sosial memiliki arti yang luas dalam ilmu sosial. Hal ini biasanya dihubungkan pada pengaruh sosial dalam pengalaman hidup individu, Dikatakan dlam bahwa kontruksi sosial memiliki beberapa kekuatan. Pertama, berperan penting dalam sentralisasi bahasa dan memberikan mekanisme yang konkret, dimana budaya mempengaruhi pikiran dan tingkah laku individu. Kedua, kontruksi sosial dapat mewakili kompleksitas dalam satu budaya tunggal, hal ini tidak mengasumsikan keseragaman. Ketiga, bersifat konsisten dengan masyarakat dan waktu.(Ngangi 2011,) 
Konstruksi sosial menyatakan tidak ada kenyataan pokok (essences) yang benar, realitas adalah kontruksi sosial oleh karena itu fenomena yang menjadi contoh dari kontruksi social adalah seperti homoseksual, hasil dari suatu budaya, bahasanya, dan juga institusi-institusi.

(Agustang, 1999) Tradisi yang dilahirkan oleh manusia merupakan adat istiadat, yakni kebiasaan namun lebih ditekankan kepada kebiasaan yang meliputi dengan nilainilai budaya, norma-norma, hukum dan aturan yang berkaitan. Manusia dan budaya memang saling mempengaruhi, baik secara langsung maupun tidak langsung. Pengaruh tersebut dimungkinkan karena kebudayaan merupakan produk dari manusia (Pujileksono 2009,) . Disetiap daerah atau tempat pasti memiliki suatu kebudaayaan yang menjadi ciri khas dari sebuah daerah. Dalam kenyataan masyarakat tidak dapat dipisahkan dari satu dengan yang lain. "Terjadi hubungan dilektika antara individu menciptakan masyarakat dan masyarakat menciptakan individu"(Prasojo 2018). Proses dialektika tersebut terjadi melalui tiga tahapan, yaitu eksternalisasi, objektifasi, dan internalisasi.

Sebagai sebuah tradisi, kearifan tradisional memiliki tata nilai dan norma sosial yang menjadi pedoman tata kelakuan masyarakat dalam persepsi, memperlakukan dan memanfaatkan potensi lingkungan alam yang ada (Wijarnako 2013). Tradisi atau kebudayaan adalah suatu keseluruhan kompleks yang meliputi pengetahuan, kepercayaan, seni, kesusilaan, hukum, adat istiadat, serta kesanggupan dan kebiasaan lainnya yang dipelajari manusia sebagai anggota masyarakat.

Menurut Linton dalam (Maryamah, 2016) Kebudayaan adalah keseluruhan dari pengetahuan, sikap dan pola perilaku yang merupakan kebiasaan yang dimiliki dan diwariskan oleh anggota suatu masyarakat tertentu. Ketika seseorang mengagumi karya agung kemanusiaan seperti Candi Borobudur dan Prambanan, tersirat pemikiran bahwa di belakang karya ini tentu ada pendidikan, pengajaran dan pelatihan yang telah tersistem dengan baik. Materi pelajaran dalam pendidikan tradisi di Nusantara umumnya secara lisan dan bersifat umum meliputi antara lain perihal kejiwaan, kefilsafahan, kesusasteraan, kanuragan, kaprajuritan, pertanian, pananggalan, adatistiadat, tata krama, perbintangan . Di daerah Toraja sendiri sebagai salah satu daerah di Indonesia yang masih sangat kental dengan nila-nilai budaya, adat isiti adat disini masih sangat terjaga dan akan kita dapatkan di setiap sudut-sudut daerah di Tanah Toraja baik itu berupa tempat wisata maupun budaya-budaya lokal. Tradisi-tradisi yang terkenal di Toraja salah satunya Rambu Tuka (Acara Suka Cita) dan Rambu Solo (Acara Duka Cita).

Si semba' merupakan sebuah tradisi turun temurun masyakarat Toraja yang dilaksanakan sebagai ungkapan kegembiraan usai melaksanakan panen padi (Abdullah, 2020). Tahun ini tepatnya pada tanggal 20 Agustus 2020 warga Kande Api menggelar tradisi pesta panen yaitu tradasi Si Semba'. Tradisi ini merupakan aksi adu kaki yang lebih terlihat seperti tawuran massal. Pasalnya, warga dari kampung tetangga, saling berhadap hadapan untuk melumpuhkan lawan, dengan cara beradu kaki "tendang" 
secara massal. Bagi peserta yang jatuh, maka lawan tidak lagi diperbolehkan menyerang. Ada cara yang digunakan agar tidak mudah jatuh, mereka saling berpegangan tangan sambil menyerang dengan tendangan kaki. Tak heran jika banyak warga yang mengalami cedera, mulai dari keseleo hingga luka terbuka akibat kerasnya tendangan lawan. Namun, jika ada peserta yang sudah dianggap terlalu kasar, maka para tokoh adat segera memisahkan mereka. Masyarakat sekarang ini sudah jarang sekali melakukan tradisi karena dianggap terlalu kasar, walaupun terlihat kasar dan keras peserta tidak membawa dendan kepada lawan.

Tradisi ini merupakan salah satu tradisi yang masih dilestarikan di era Modernisasi ini, dilihat dari tempat peneilitian ini yang berada di keramaian dan masih bisa disebut sebagai sentral atau kota. Ini membuktikan bahwa masyarakat sekitar Kande Api, Tikala tetap menerima dan bersuka cita jika diadakannya tradisi ini. Max Weber secara detail memaparkan, masyarakat modern merupakan masyarakat yang sudah mengalami proses perubahan berfikir dari awalnya percaya terhadap hal-hal yang bersifat mistis atau takhayul kemudian beralih menjadi lebih berpengetahuan dan cenderung lebih rasional. (Yulistiana, 2013)

Dahulu tradisi ini masih sering dilakukan di berbagai daerah tetapi karena beberapa faktor membuat tradisi ini mulai terkikis. Menurut pemaparan warga sekitar desa Kandeapi, tradisi Si Semba' di kampungnya dari dulu sampai era modernisasi sekarang masih rutin diadakan walaupun sudah banyak aturan yang mulai diubah, seperti misalnya dahulu semua masyarakat diperbolehkan untuk ikut serta tetapi sekarang hanya pemuda berusia 20 tahun keatas yang bisa ikut serta. Tradisi ini bisa dikembangkan dan terus dilestarikan oleh manusia ke manusia yang lainnya demi menjada eksistensi dari sebuah budaya, dan dapat berlangsung secara terus menerus sehingga menjadi suatu kebiasaan. Tradisi yang memang sudah ada sejak jaman nenek moyang dan terus diturunkan kepada kita yang masih dapat terus melestarikannya.

Dari penjelasana diatas dapat disimpulkan bahwa tahapan eksternalisasi lebih dominan, dimana realitanya sebuah tradisi tidak terlepas dari kebiasaan yang memang sudah dilaksanakan sejak dulu dan tetap dilestarikan sampai sekarang, masyarakat sekitar Tikala pun yang tidak ikut serta dalam tradisi Si Semba' tetap mendukung dan menikmati adanya tradisi ini, walaupun berada di tengah kota tradisi ini tidak akan terkikis oleh modernisasi jika kita sebagai masyarakat dapat melestarikan dan menjaga tradisi maupun adat istiadat dengan baik, upaya mempertahankan eksistensi suatu tradisi dilakukan melalui jalinan relasi sosial dalam pertalian dari hubungan dalam anggota masyarakat, sekaligus sebagai langkah nyata tradisi tersebut dalam mepertahankan budaya dan adat istiadat turun temurun. Konstruksi masyarakat terhadap suatu tradisi yang demikian itu kemudian diimplementasikan dalam berbagai bentuk tradisi ritual sebagai ungkapan syukur dan permohonan agar warga senantiasadiberi perlindungan dan keselamatan. 


\section{METODE PENELITIAN}

Jenis penelitian yang digunakan yaitu mengunakan metode kualitatif dengan menggunakan pendektan deskriptif. Adapun fokus penelitian ini adalah masyarakat Desa Kandeapi Tikala Toraja Utara, terkait pandanga atau pemahaman mereka mengenai tradisi si semba', nilai pendidikan yang terkandung dalam tradisi si semba', dan faktor pendukung eksistensi tradisi si semba' di era globalisasi. Adapun tahaptahap dalam penelitian ini adalah tahap pra penelitian, tahap penelitian dan tahap akhir. Sumber data yang digunakan yaitu sumber data primer dan sumber data sekunder. Jumlah informan sebanyak 10 orang yang dipilih menggunakan teknik purposive sampling. Teknik pengumpulan data dengan metode observasi, wawancara dan dokumentasi. Pengecekan keabsahan data menggunakan teknik member check. Teknik analisis data meliputi reduksi data, penyajian data, dan kesimpulan (Agustang, 2021).

\section{PEMBAHASAN}

\section{Konstruksi Sosial Masyarakat Terhadap Tradisi Si Semba'}

Teori konstruksi sosial (social construction) Berger dan Lukmann merupakan teori sosiologi kontemporer yang berpijak pada sosiologi pengetahuan. Dalam teori ini terkandung pemahaman bahwa kenyataan dibangun secara sosial, serta kenyataan dan pengetahuan merupakan dua istilah kunci untuk memahaminya. Kenyataan adalah suatu kualitas yang terdapat dalam fenomena-fenomena yang diakui memiliki keberadaan sendiri sehingga tidak tergantung kepada kehendak manusia, sedangkan pengetahuan adalah kepastian bahwa fenomen-fenomen itu nyata (real) dan memiliki karakteristik yang spesifik. Oleh karena konstruksi sosial merupakan sosiologi pengetahuan maka implikasinya harus menekuni pengetahuan yang ada dalam masyarakat dan sekaligus proses-proses yang membuat setiap perangkat pengetahuan yang ditetapkan sebagai kenyataan. Sosiologi pengetahuan harus menekuni apa saja yang dianggap sebagai pengetahuan dalam masyarakat.

Berger dan Luckman (Bungin, 2008) mengatakan terjadi dialektika antara individu menciptakan masyarakat dan masyarakat menciptakan individu. Proses dialektika ini terjadi melalui eksternalisasi, objektivasi, dan internalisasi. Dari hasil penelitian yang telah dilakukan dapat ditarik kesimpulan mengenai konstruksi sosial masyarakat terhadap tradisi si semba' merupakan tradisi turun temurun yang di masih pantas untuk dilestarikan karena mengandung nilai-nilai spiritual dan menjadi bagian dari budaya, Adapun bentuk dari konstruksi sosial mengikut dengan tiga tahapan menurut Peter L Berger.

1. Eksternalisasi

Eksternalisasi adalah proses ketika sebuah produk sosial telah menjadi sebuah bagian penting dalam masyarakat yang setiap saat dibutuhkan dalam individu, maka produk sosial itu menjadi bagian penting dalam kehidupan seseorang untuk melihat dunia luar. Eksternalisasi adalah suatu pencurahan kedirian manusia terus-menerus ke dalam dunia, baik dalam aktivitas fisis maupun mentalnya. Yang dimaksud Kedirian manusia 
adalah melakukan eksternalisasi yang terjadi sejak awal, untuk menjadi manusia, ia harus mengalami perkembangan kepribadian dan perolehan budaya. Dalam penelitian ini adaptasi yang terjadi pada lingkup masyarakat setempat bahwa tradisi si semba merupakan tradisi yang sudah ada sejak jaman nenek moyang dan mandarah daging. Sejak masih kecil hingga dewasa mereka sudah tumbuh bersama dengan tradisi, seiring berjalannya waktu mereka jadi paham sendiri mengenai budaya karena telah dibiasakan sedari kecil hidup berdampingan dengan adat istiadat. Ini membuktikan bahwa masyarakat desa Kandeapi Tikala sangat menghargai unsur-unsur budaya dan adat istiadat, karena mereka senantiasa menjaga harta mereka yaitu budaya mereka sendiri.

2. Eksternalisasi

Bagi Berger, masyarakat adalah produk manusia, berakar pada fenomena eksternalisasi. Produk manusia (termasuk dunianya sendiri), kemudian berada di luar dirinya, menghadapkan produk-produk sebagai faktisitas yang ada di luar dirinya. Meskipun semua produk kebudayaan berasal dari (berakar dalam) kesadaran manusia, namun produk bukan serta-merta dapat diserap kembali begitu saja ke dalam kesadaran. Kemampuan ekspresi diri manusia mampu mengadakan obyektivasi (objectivation), artinya ia memanifestasikan diri dalam produk-produk kegiatan manusia yang tersedia, baik bagi produsenprodusennya maupun bagi orang lain sebagai unsur-unsur dari dunia bersama. Obyektivasi itu merupakan isyarat-isyarat yang sedikit banyaknya tahan lama dari proses-proses subyektif para produsennya, sehingga memungkinkan obyektivasi itu dapat dipakai sampai melampaui situasi tatap muka dimana mereka dapat dipahami secara langsung

Tahap objektivitasi terjadi jika suatu keadaan dilakukan secara berulang. Keadaan yang berulang ini menyadarkan individu bahwa realitanya tradisi ini rutin dilaksanakan sejak dulu (Rorong, 2020). Walaupun dahulu dilaksanakan pada saat acara kematian bangswan namun sekarang hanya dilaksanakan pada acara panen saja. Karena rutin diadakan maka tradisi ini sudah menjadi kebiasaan yang dilangsungkan setiap tahun, semua orang menunggu dilaksanakannya tradisi ini. Dari hasil penelitian yang dilakukan peneiliti ada beberapa perdebatan untuk melestarikan tradisi ini, dari 12 informan ada 4 informan menganggap tradisi ini mengandung unsur kekerasan dan beberapa daerah di Toraja sendiri sudah banyak yang menghapuskan tradisi ini. Namun masyarakat desa Kandeapi tetap mempertahankan tradisi ini karena dianggap masih bisa mematuhi peraturan permainan dan waktu yang diberikan dipersingkat. Mereka menganggap bahwa tradisi ini sudah menjadi bagian dari adta istiadat yang langka dan harus tetap dilestarikan. Gejala ini relevan dengan teori konstruksi sosial Berger \& Luckmann (1991) bahwa dalam tahapan objektivasi, pengetahuan individu berbeda antara satu dengan lain bergantung pada faktor yang berpengaruh di luar individu.

\section{Internalisasi}

Internalisasi proses pemahaman atau penafsiran langsung dari suatu peristiwa objektif sebagai pengungkapan suatu makna, artinya sebagai manifestasi dari proses-proses subjektif orang lain, yang demikian menjadi bermakna subjektif bagi individu itu 
sendiri. Berger dan Luckmann (1990: 87) menyatakan, dalam internalisasi, individu mengidentifikasikan diri dengan berbagai lembaga sosial atau organisasi sosial di mana individu menjadi anggotanya. Internalisasi merupakan peresapan kembali realitas oleh manusia dan mentransformasikannya kembali dari struktur-struktur dunia objektif ke dalam struktur-struktur kesadaran subjektif.

Pada tahap internalisasi individu akan memakanai apa yang menjadi realitas, mereka akan menyerap segala hal yang bersifat objektif. Awalnya masyarakat tua sangat tidak setuju jika tradisi ini ditiadakan karena akan mengugurkan kebudayaan yang telah lama tercipta, tetapi keadaan realitasnya di berbagai daerah di Toraja Utara sendiri telah meghapuskan tradisi si semba'. Perbedaan pendapat ini masih terjadi sampai sekarang, banyak dari masyarakat yang menganggap bahwa tradisi memang sudah harus dihapuskan mengingat banyak daerah-daerah lain yang menghapuskan tradisi ini, tetapi 8 dari informan masih ingin melestarikan budaya ini karena mereka masih bisa patuh pada aturan. Dari hasil penelitian di dapatkan bahwa bentuk konstruksi sosial maysrakat terhadapat tradisi si semba' yang dominan adalah tahapan eksternalisasi karena budaya atau tradisi yang ada di desa Kandeapi lahir sejak zaman dahulu dan mereka sudah tumbuh bersama dengan tradisi. Gaya hidup yang di bilang masih tradisional membuktikan bahwa masyarakat desa Kandeapi tidak bisa jauh dari adat, dan mereka sudah merasa bahwa tradisi adalah bagian dari mereka.

\section{Nilai Pendidikan yang Terkandung dalam Tradisi Si Semba'}

Pendidikan dikatakan ilmu pendidikan atau pedagogi merupakan disiplin ilmu yang terkait dengan proses pemeradaban, pemberbudayaan, dan pendewasaan manusia (Normina, 2018). Salah satu upaya untuk membangun dan meningkatkan mutu sumber daya manusia menuju era globalisasi yang penuh dengan tantangan, sehingga pendidikan merupakan sesuatu yang sangat fundamental bagi setiap individu. Pada dasarnya suatu kelompok masyarakat atau bangsa memiliki pandangan hidup yang diwarisinya dari zaman ke zaman dan merupakan nilai-nilai yang diyakini kebenarannya. Bagaimanapun rendahnya tingkat kebudayaan suatu masyarakat atau bangsa tetap memiliki sesuatu yang dianggapnya berharga. Dengan demikian pendidikan selalu berusaha mewariskan sesuatu yang bermanfaat dan dianggap baik kepada generasi mudanya.

Manusia dan kebudayaan merupakan satu kesatuan yang tidak terpisahkan, sementara itu pendukung kebudayaan adalah makhluk manusia itu sendiri (Karsidi, 2005). Sekalipun makhluk manusia akan mati, tetapi kebudayaan yang dimilikinya akan diwariskan pada keturunannya, demikian seterusnya. Pewarisan kebudayaan makhluk manusia, tidak selalu terjadi secara vertikal atau kepada anak-cucu mereka; melainkan dapat pula secara horizontal yaitu manusia yang satu dapat belajar kebudayaan dari manusia lainnya.

Berbagai pengalaman dalam rangka kebudayaannya, diteruskan dan dikomunikasikan kepada generasi berikutnya oleh individu lain. Berbagai gagasannya 
dapat dikomunikasikannya kepada orang lain karena ia mampu mengembangkan gagasangagasannya itu dalam bentuk lambang-lambang vokal berupa bahasa, baik lisan maupun tulisan.

Sejalan dengan teori kontsruksi sosial oleh Peter L. Berger yang membahsa tentang "kenyataan" dan "pengetahun" . Kehidupan sehari-hari telah menyimpan dan menyediakan kenyataan, sekaligus pengetahuan yang membimbing perilaku dalam kehidupan sehari-hari. Kehidupan sehari-hari menampilkan realitas obyektif yang ditafsirkan oleh individu, atau memiliki makna-makna subyektif. Di sisi 'lain', kehidupan sehari-hari merupakan suatu dunia yang berasal dari pikiran-pikiran dan tindakan-tindakan individu, dan dipelihara sebagai 'yang nyata' oleh pikiran dan tindakan itu. Dasar-dasar pengetahuan tersebut diperoleh melalui obyektivasi dari proses-proses (dan makna-makna) subyektif yang membentuk dunia akal-sehat intersubyektif (Sulaiman, 2016). Pengetahuan akal-sehat adalah pengetahuan yang dimiliki bersama (oleh individu dengan individu-individu lainnya) dalam kegiatan rutin yang normal (dalam kehidupan sehari-hari).

(Pratama) Tradisi merupakan budaya yang menjadi bagian dari kebiasaan masyarakat di Toraja. Mereka lahir dan besar bersama dengan tradisi, mereka melihat dan mempelajari budaya tanpa di sengaja. Kebiasaan-kebiasaan yang dilakukan terus menerus membuat masyarakat merasa bahwa itu adalah bagian dari mereka. Namun dibalik uniknya tradisi-tradisi yang dimiliki Toraja banyak tradisi yang ditentang atau mendatangkan pro dan kontra dari masyarakat, terutama seiring dengan berkembangnya modernisasi membuat banyak tradisi yang tenggelam. Tradisi si semba' sendiri yang sudah ada sejak dahulu kala sudah banyak di hapuskan di beberapa daerah, contohnya di desa Tallunglipu sudah menghapuskan tradisi ini karena dianggap mengandung banyak unsur kekerasan, dan beberapa desa lain yang letaknya tidak jauh dari kota. Desa Kandeapi yang berada tidak jauh dari kota masih sering melaksanakan tradisi si semba', 10 dari 12 informan masih menganggap bahwa tradisi ini merupakan tradisi yang sakral. Biasanya tradisi ini dilaksanakan saat ada pesta kematian atau Rambu Solo para bangsawan, setelah acara silaga tedong (adu kerbau) mereka melanjutkan dengan acara si semba' (adu kaki) lalu dilanjutkan dengan istirahat dan makan. Durasi yang diberikan juga sekarang sudah dipersingkat hanya sekitar satu sampai dua jam saja, jika dianggap sudah banyak yang melanggar maka permainan akan dihentikan.

Dari hasil penelitian didapatkan bahwa masyarakat desa Kandeapi Tikala sangat menghargai sebuah tradisi. Mereka menganggap bahwa tradisi ini sebenarnya mengandung nilai-nilai tradisional yang sangat kental. Konon katanya para pemain diberikan mantra oleh kepala adat agar bila terkena tendangan tidak mengalami cedera, buktinya sampai saat ini belum ada kasus warga yang cedera parah akibat tradisi ini. Selain itu tradisi ini juga bertujuan untuk menjalin silaturahmi dengan masyarakat yang berdatangan dari desa lain, terutama warga dari desa pengunungan yang jarang mereka temui. Dari tujuan itulah mengajarkan kita bahwa bersosialisasi dengan orang lain itu 
penting, kita dapat bertemu dan mendapat pengetahuan baru dari orang-orang yag dijumpai. Setelah acara si semba' dilaksanakan mereka lalu saling menyapa dan bertukar cerita tanpa menyimpan rasa dendam, karena orang Toraja percaya bahwa dendam itu membawa petaka pada acara kematian, hal ini mengajarkan kita untuk saling memaafkan dan memiliki sifat yang lebih dewasa dengan melawan ego. Dianggap mengandung unsur kekerasan karena banyak orang yang membawa masalah pribadi ke dalam arena, seperti anak muda yang memliki masalah percintaan akan membawanya ke arena dan melampiaskan amarah pada saat permainan dimulai. Maka itulah mengapa salah satu peraturan dalam tradisi ini bahwa para lawan tidak saling mengenal agar mereka tidak membawa dendam. Masyarakat desa Kandeapi sangat setuju jika tradisi si semba' ini tetap dilestarikan dan tidak dihapuskan. Dibalik tata cara permainannya yang dianggap mengandung kekerasan ternyata ada nilai positif, itulah makna dari sebuah tradisi. Karena sebuah tradisi lahir untuk memberikan makna dan tujuan yang baik pada masyarakat.

\section{Faktor Pendukung Eksistensi Tradisi Si Semba'di era Blobalisasi}

Seiring dengan perkembangan dan perubahan sosial yang mengakibatkan berbagai tradisi dan kebudayaan daerah yang pada awalnya dipegang teguh, dijunjung tinggi,di pelihara dan dijaga keberadaannya oleh setiap etnis, kini sudah hampir punah dan luntur dalam kehidupan masyarakat. Pada dasarnya masyarakat yang sangat sesuai dengan kepribadian daerahnya. Secara teori, budaya banyak mengandung nilai-nilai yang menjadi petuah dan nasehat yang diturunkan secara turun temurun oleh nenek moyang yang sampai hari ini masih dijunjung tinggi oleh sebagian masyarakat (Widiansyah \& Hamsah, 2018).

Nilai-nilai tersebut telah diwujudkan dalam pola tingkah laku masyarakat dalam kehidupan keseharian. Umumnya masyarakat lebih tertarik untuk menampilkan dan menggunakan berbagai produk, kesenian dan budaya modern daripada budaya yang berasal dari daerahnya sendiri yang sesungguhnya justru budaya daerah atau budaya lokalah beberapa nilai-nilai seiring dengan perkembangan globalisasi.

Dampak yang terjadi pada tradisi si semba' di desa Kandeapi adalah ada beberapa aturan yang berubah, dari hasil penelitian 5 dari informan mengatakan bahwa perubahan yang sangat jelas adalah adanya beberapa acara yang dihapuskan seperti massaung dan durasi main yang sangat dipersingkat. Eksistensi globalisasi membuat tradisi si semba' tetap ada di desa Kandeapi Tikala karena dianggap masih bisa dipertanggung jawabkan dan masyarakat setempat pun ingin melestarikan tradisi tersebut, ini sejalan dengan hasil wawancara penulis oleh ke-5 informan yang merasa bahwa jika tradisi ini dihapuskan akan mambuat mereka kehilangan salah satu dari budaya mereka yang sudah ada sejak mereka kecil. Pengaruh globalisasi yang terjadi sekarang tidak menganggu berjalannya tradisi-tradisi di Toraja, tapi masyarakat terbantu oleh perkembangan teknologi yang mereka manfaatkan sebagai wadah untuk mempromosikan budaya. 6 informan mengatakan bahwa salah satu cara untuk 
melestarikan budaya terkhusus tradisi si semba' ini dengan mengandalkan media sosial, anak muda yang merantau juga bisa mengenalkan tradisi kepada orang lain. Para pemuda sangat berperan penting dalam pelestarian budaya karena mereka dianggap mampu dan mempunyai pengetahuan yang lebih. Tradisi si semba' sekarang malah diramaikan oleh pemuda-pemuda yang mempunyai semangat yang tinggi, ini juga berdampak baik bagi pelestarian budaya, Kembali lagi kepada tujuan dari tradisi ini adalah untuk menjalin silaturahmi.

\section{PENUTUP}

Berdasarkan hasil penelitian yang dilakukan terhadap masyarakat desa Kandeapi maka dapat di simpulkan sebagai berikut: 1.) Konstruksi sosial masyarakat terhadap tradisi si semba' di desa Kandeapi Tikala berdasarkan hasil penelitian adalah tradisi ini merupakan permainan adu kaki yang dilaksanakan setiap musim panen tiba sebagai bentuk rasa syukur, masyarakat setempat sepakat bahwa tradisi ini merupakan tradisi yang sudah turun temurun dan masih bisa untuk dilestarikan karena dianggap masih memiliki nilai-nilai yang berharga bagi masyarakat setempat. Konstruksi sosial masyarakat terhadap tradisi si semba' terbentuk oleh 3 tahap yaitu a) Tahap eksternalisasi dimana tradisi ini merupakan tradisi yang mandarah daging dan sudah ada sejak zaman nenek moyang, b) Objektivasi pada tahapan ini tradisi terbentuk karena adanya kebiasaan-kebiasan yang dilakukan oleh masyarakat setempat, c) Internalisasi yaitu tahapan dimana masyarakat masih ingin melestarikan tradisi ini karena dianggap masih berharga. 2.) Nilai pendidikan yang terkandung dalam tradisi si semba' adalah walaupun tradisi ini dianggap mengandung unsur kekerasan namun tradisi ini bertujuan untuk membangun jiwa kebersamaan, kekompakan, dan dijadikan sebagai ajang silaturahmi. Dengan adanya rasa menghargai satu sama lain membuat masyarakat yang ikut bermain tidak menyimpan dendam setelah permainan dilaksanakan. Ini dapat mengarjakan kita bahwa bersosialisasi itu penting dan menumbuhkan jiwa kedewasaan dalam diri untuk melawan emosi. 3.) Faktor pendukung eksistensi tradisi si semba' adalah pengaruh globalisasi yang banyak mengikis budaya-budaya tradisional tidak menjadi hambatan di desa Kandeapi, mereka menggunakan perubahan teknologi menjadi salah satu metode untuk melestarikan budaya mereka. Dengan memanfaatkan media sosial membagikan kegiatan-kegiatan tradisional termasuk tradisi si semba' membuat orang-orang yang tadinya tidak tau menjadi mulai tertarik dengan tradisi si semba' . Ini juga dapat menguntungkan masyarakat setempat termasuk Pariwisata Toraja dan Perekonomian daerah.

\section{DAFTAR PUSTAKA}

Abdullah, M. Q. (2020). Riset Budaya: Mempertahankan Tradisi Di Tengah Krisis Moralitas.

Agustang, A. (1999). INTERAKSI SOSIAL DAN PERUBAHAN STRUKTUR KOMUNITAS. Universitas Padjadjaran Bandung.

Agustang, A. (2021, January 22). Filosofi Research Dalam Upaya Pengembangan Ilmu. https://doi.org/10.31219/osf.io/9n6za 
Agustang, A., \& Oruh, S. (2021, January 22). Teknologi Partisipasi Metode Fasilitasi Pembuatan Keputusan Partisipatif. https://doi.org/10.31219/osf.io/dhfb7

Bungin, B. (2008). Konstruksi Sosial Media Massa:Kekuataan Pengaruh Media IklasTelevisi, dan Keputusan Konsumen Serta Kritik Terhadap Peter L.Berger \&Thomas Luckman. Prenadamedia Group.

Karsidi, D. (2005). Sosiologi pendidikan.

Maryamah, E. (2016). Pengembangan Budaya Sekolah. Tarbawi: Jurnal Keilmuan Manajemen Pendidikan, 2(02), 86-96.

Ngangi, C. R. (2011). Konstruksi sosial dalam realitas sosial. Agri-Sosioekonomi, 7(2), $1-4$.

Normina, N. (2018). Pendidikan dalam Kebudayaan. ITTIHAD, 15(28), 17-28.

Prasojo, M. N. B. (2018). Konstruksi Sosial Masyarakat Terhadap Alam Gunung Merapi: Studi Kualitatif tentang Kearifan Lokal yang Berkembang di Desa Tlogolele Kecamatan Selo Kabupaten Boyolali. Jurnal Analisa Sosiologi, 4(2).

Pratama, W. A. (n.d.). Paradigma Hukum Adat (Hukum Dalam Prespektif Masyarakat Hukum Adat). GUEPEDIA.

Pujileksono, S. (2009). Pengantar antropologi. UMM press.

Rorong, M. J. (2020). Fenomenologi. Deepublish.

Sulaiman, A. (2016). Memahami Teori Konstruksi Sosial Peter L. Berger. Society, 4(1), 15-22.

Widiansyah, S., \& Hamsah, H. (2018). Dampak Perubahan Global terhadap Nilai-nilai Budaya Lokal dan Nasional. Hermeneutika: Jurnal Hermeneutika, 4(1), 3948.

Wijarnako, B. (2013). PEWARISAN NILAI-NILAI KEARIFAN TRADISIONAL DALAM MASYARAKAT ADAT (Peranan Kepala Adat dalam Mewariskan aturan Adat di Kampung Adat Dukuh Desa Cijambe, Kecamatan Cikelet, Kabupaten Garut, Propinsi Jawa Barat). Jurnal Geografi Gea, 13(2).

Yulistiana, T. (2013). Pengaruh Modernisasi Terhadap Perubahan Pemaknaan Tradisi Lokal Jawa Mendhem Ari-Ari. Skripsi . Universitas Islam Negeri Sunan Kalijaga. 